\title{
Auxology, Kurva Pertumbuhan, Antropometri, dan Pemantauan Pertumbuhan
}

\author{
Aman B. Pulungan \\ Departemen Ilmu Kesehatan Anak Fakultas Kedokteran Universitas Indonesia/RSUPN Cipto Mangunkusumo, Jakarta
}

Pertumbuhan anak adalah suatu proses dinamis. Untuk mengetahui bagaimana seorang anak bertumbuh dibandingkan dengan anak sebayanya, diperlukan kurva pertumbuhan sebagai alat pembanding. Kurva pertumbuhan telah digunakan dalam pemantauan perkembangan anak sejak abad ke-18. Berbagai kurva pernah dikembangkan, termasuk kurva referensi dan kurva standar, seperti kurva referensi nasional yang dikembangkan di banyak negara dan kurva standar World Health Organization (WHO) yang digunakan secara internasional sejak tahun 2006. Pemantauan pertumbuhan dilakukan dengan melakukan plot hasil pengukuran ke grafik pertumbuhan, selanjutnya dibandingkan dengan pengukuran sebelumnya. Oleh karena itu, pemantauan pertumbuhan anak secara berkala penting dilakukan. Pengukuran pertumbuhan dengan teknik yang tepat disertai dengan anamnesis dan pemeriksaan fisik dapat mengenali gangguan pertumbuhan sejak dini. Deteksi dini gangguan pertumbuhan menjadi tugas penting orangtua dan tenaga kesehatan. Abnormalitas pertumbuhan juga dapat menandai adanya penyakit dasar yang bersifat kronik serius. Keterlambatan diagnosis dan tata laksana gangguan pertumbuhan menyebabkan potensi genetik anak untuk tinggi tidak tercapai dan anak menjadi pendek. Sari Pediatri 2020;22(2):123-30

Kata kunci: kurva pertumbuhan, pertumbuhan anak, antropometri anak

\section{Auxology, Growth Charts, Anthropometry, and Growth Monitoring}

Aman B. Pulungan

Growth in children is a dynamic process. To compare the growth of a child to his/her peers, the growth chart is a valuable tool. Growth charts have been used to track children's growth since the $18^{\text {th }}$ century. Various growth charts have been developed, including reference and standard charts such as the World Health Organization's (WHO) standard growth chart, which has been used internationally since 2006. Despite being a part of the daily clinical practice the implementation of growth monitoring is not yet optimal. Growth is monitored by plotting the results of anthropometric measurements to a growth chart and compare the measurements with previous ones. Thus, it is important to measure a child's growth periodically. Combined with history and physical examination, appropriate measurement and monitoring of a child's growth can help with early diagnosis of growth disturbances, which may be a sign of underlying chronic diseases. Delayed diagnosis and treatment of growth abnormalities can cause the failure of achieving a child's genetic height potential, leading to short stature. Sari Pediatri 2020;22(2):123-30

Keywords: growth chart, growth, anthropometry

Alamat korespondensi: Aman B. Pulungan. Departemen Ilmu Kesehatan Anak, Fakultas Kedokteran Universitas Indonesia - Rumah Sakit Cipto Mangunkusumo, Jakarta, Indonesia 10430. Email: amanpulungan@mac.com 
Aman B. Pulungan: Auxology, kurva pertumbuhan, antropometri, dan pemantauan pertumbuhan

$\mathrm{P}$ enggunaan kurva pertumbuhan untuk memantau dan mendeteksi masalah kesehatan anak sejak dini penting dilakukan. Sejak pertama kali diperkenalkan pada abad ke-18, penggunaan kurva pertumbuhan sebagai alat untuk menilai pertumbuhan anak telah meluas. ${ }^{1}$ Berbagai kurva dikembangkan, di antaranya adalah kurva National Centers for Health Statistics (NCHS) pada tahun 1977 yang kemudian digantikan oleh kurva Centers for Disease Control and Prevention (CDC) pada tahun $2000^{2}$ dan kurva standar WHO tahun 2006. ${ }^{3}$ Selain kedua kurva tersebut, banyak negara mengembangkan kurva nasional masing-masing.

Kurva WHO merupakan kurva standar yang mengambil populasi dari beberapa negara maju dan berkembang di dunia dan mendeskripsikan bagaimana anak sehat tumbuh dalam kondisi optimal. Sementara itu, kurva CDC dan kurva nasional lain merupakan kurva referensi yang mendeskripsikan pertumbuhan sekelompok anak pada waktu dan tempat tertentu. ${ }^{4}$ Dengan demikian, terdapat perbedaan dalam interpretasi kedua jenis kurva tersebut.

Sebelum kurva WHO digunakan sebagai kurva standar, beberapa kurva lain sempat digunakan. Pada tahun 1949, HV Meredith menerbitkan kurva untuk memantau pertumbuhan anak di Amerika Serikat, tetapi dianggap tidak representatif karena dibuat berdasarkan data anak-anak yang berasal dari keluarga dengan status sosioekonomi tinggi saja. Kemudian, pada tahun 1960-1970, kurva pertumbuhan Harvard disempurnakan dan disosialisasikan secara luas oleh WHO untuk digunakan sebagai referensi pertumbuhan internasional. Kurva Harvard tersebut juga dicantumkan dalam Nelson's Textbook of Pediatrics. Namun, kurva Harvard dianggap memiliki berbagai kekurangan, seperti kecilnya jumlah anak yang digunakan sebagai sampel dan latar belakang genetik anak-anak yang kurang beragam. Pada tahun 1974, kurva dari National Center for Health Statistics (NCHS) dan CDC di Amerika Serikat dikembangkan, dan dianggap sesuai untuk digunakan sebagai referensi pertumbuhan internasional. ${ }^{5}$ Pengembangan kurva-kurva tersebut menjadi cikal bakal dibuatnya kurva WHO yang digunakan saat ini.

Berbagai studi meneliti penggunaan kurva standar WHO di negara berkembang. Kerac $\mathrm{dkk}^{6}$ meneliti status gizi kurang dan buruk di 21 negara berkembang. Didapatkan bahwa prevalensi gizi kurang dan buruk pada anak di bawah 6 bulan menggunakan kurva referensi NCHS adalah 1,1$15 \%$, sementara dengan kurva standar WHO angka ini lebih tinggi, yaitu 2-34\%. Serupa dengan hasil penelitian tersebut, Johnson $\mathrm{dkk}^{7}$ di pedalaman Andhra Pradesh, India, melaporkan bahwa kurva WHO secara signifikan cenderung mengklasifikasikan anak usia 3-7 bulan sebagai berat badan kurang dibandingkan kurva NCHS, sebaliknya setelah usia 10 bulan kecenderungan mengklasifikasikan anak sebagai berat badan kurang lebih rendah. Selain itu, dengan kurva WHO didapatkan lebih banyak anak dengan stunting. Di Indonesia sendiri, beberapa kurva pernah dikembangkan untuk menjadi kurva referensi pertumbuhan anak Indonesia, seperti kurva Jumadias, Yayah-Husaini, dan kurva hasil penelitian Batubara dkk. Hingga saat ini sudah dikembangkan kurva referensi pertumbuhan anak Indonesia karya Pulungan dkk. ${ }^{8,9}$

\section{Auxology dan sejarah kurva pertumbuhan}

Auxology adalah ilmu yang mempelajari pertumbuhan manusia. Di dalamnya termasuk bagaimana kita mengukur dan memantau pertumbuhan anak dan remaja, pembuatan dan penggunaan kurva pertumbuhan, serta bagaimana faktor-faktor internal dan eksternal memengaruhi pertumbuhan seseorang. Pertumbuhan manusia adalah suatu proses yang dinamis sehingga pencatatan yang lengkap dan sistematis adalah hal yang penting. ${ }^{10}$ Untuk mengetahui apakah pertumbuhan seorang anak bisa dianggap sesuai dengan pertumbuhan yang seharusnya untuk anak seusianya, diperlukan suatu pembanding yang menyajikan pola pertumbuhan anak sehat seiring dengan bertambahnya umur, yaitu kurva pertumbuhan.

Kurva pertumbuhan pertama yang terdokumentasi adalah oleh Count Philibert Gueneau de Montbeillard. Ia mencatat dan melakukan plotting tinggi badan dan kenaikan tinggi badan per tahun anak laki-lakinya setiap 6 bulan, dari usia 0-18 tahun pada tahun 17591777. Berdasarkan kurva tersebut, dapat dilihat bahwa terdapat fase deselerasi yang cepat pada masa bayi, diikuti oleh fase deselerasi yang lebih stagnan dan lambat pada masa anak, lalu terjadi pacu pertumbuhan pada pertengahan masa anak (antara usia 5-9 tahun), dan pacu pertumbuhan remaja yang terjadi pada usia 12 tahun pada anak laki-laki. ${ }^{11}$

Di Jerman, pada tahun 1839, Günther mencatat 

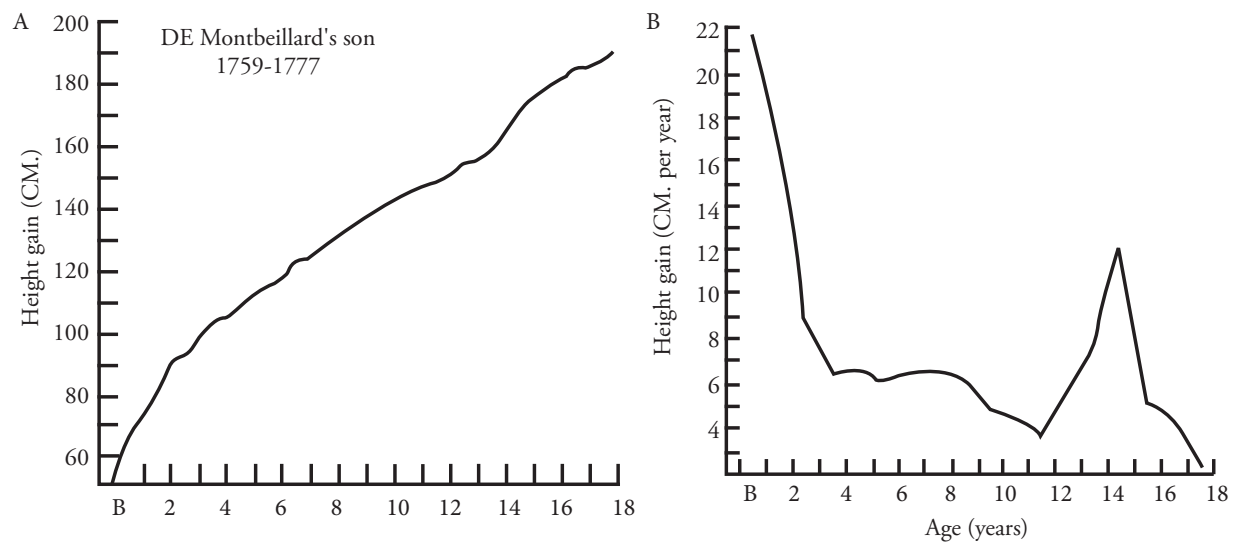

Gambar 1. Kurva dari anak laki-laki de Montbeillard

$(1759-1777)^{11}$

pertambahan tinggi badan pada 33 anak laki-laki dengan usia tang berbeda-beda. Lalu, Kotelmann pada tahun 1879 adalah ilmuwan yang pertama menyadari adanya pacu tumbuh (growth spurt), yang merupakan sebuah penemuan signifikan pada sejarah ilmu pertumbuhan manusia. Sebelumnya, pada tahun 1829, Louis René Villermé adalah yang pertama kali menyadari pertumbuhan dan tinggi dewasa seorang anak dipengaruhi oleh status sosioekonomi negara tempat tinggalnya. Kemudian disadari bahwa remaja yang merupakan bagian dari populasi yang tinggi dan memiliki status sosioekonomi baik mengalami pacu tumbuh yang lebih pesat. ${ }^{12}$

Dalam mendokumentasikan pertumbuhan, ada dua jenis kurva, yaitu kurva referensi pertumbuhan dan kurva standar pertumbuhan. Kurva referensi pertumbuhan mendeskripsikan bagaimana anak tumbuh. Sementara kurva standar pertumbuhan menggambarkan bagaimana anak seharusnya tumbuh. Kurva pertumbuhan yang digunakan untuk membandingkan berat badan, tinggi badan, dan parameter pertumbuhan lain, sebaiknya disesuaikan dengan populasi individu yang pertumbuhannya diukur.

Badan kesehatan dunia WHO membuat kurva pertumbuhan standar di tahun 2006, dibuat berdasarkan pola pertumbuhan longitudinal anak berusia 0-24 bulan dan data potong lintang dari anak berusia 18-71 bulan dari berbagai negara, seperti Brazil, Ghana, India, Norwegia, Oman, dan Amerika Serikat. Data anak yang digunakan ini tinggal di lingkungan yang baik, mendapatkan ASI selama minimal 4 bulan, memulai makanan pendamping ASI pada usia 6 bulan, dan melanjutkan ASI hingga paling tidak usia 12 bulan. ${ }^{13}$

\section{Pemantauan pertumbuhan}

Kunjungan ke dokter secara berkala pada dua tahun pertama kehidupan anak merupakan hal yang penting dilakukan. Tidak hanya pemeriksaan fisik, pemantauan perkembangan, nutrisi, sikap dan perilaku juga dilakukan. Salah satu peran dokter anak adalah membantu tiap anak mencapai potensi terbaiknya dengan monitor dan skrining pertumbuhan dan perkembangan. American Academy of Pediatrics merekomendasikan kunjungan ke dokter pada usia 2 minggu, 1, 2, 4, 6, 9, 12, 15, 18 bulan, 2, 3 tahun, dan dilanjutkan tiap tahun hingga usia remaja. ${ }^{14}$ Ikatan Dokter Anak Indonesia merekomendasikan pemantauan pertumbuhan tiap bulan untuk balita, untuk tinggi badan pada anak $<1$ tahun diperiksakan saat lahir, 1, 2, 4, 6, 9, 12 bulan; usia 1-2 tahun setiap 3 bulan, $>3-21$ tahun setiap tahun. ${ }^{15}$

Abnormalitas pada pola pertumbuhan mungkin tidak spesifik, tetapi penting sebagai penanda kemungkinan penyakit kronik serius. Oleh karena itu, pengukuran indikator pertumbuhan (panjang/ tinggi badan, berat badan, dan lingkar kepala) harus dilakukan secara akurat pada tiap kunjungan. Tabel 1 menunjukkan kriteria standar untuk mengevaluasi pertumbuhan anak. Pengukuran secara berkala tentunya lebih bermakna jika dibandingkan sekali pengukuran. ${ }^{14}$

Pemantauan pertumbuhan dilakukan dengan melakukan plot hasil pengukuran ke grafik pertumbuhan dan membandingkannya dengan pengukuran sebelumnya. Anak dengan kondisi khusus, seperti berat lahir sangat rendah (<1500 gram), Sindrom Turner, Sindrom 
Down, akondroplasia, dan sindrom dismorfik lainnya menggunakan kurva pertumbuhan yang berbeda.

Empat kurva pertumbuhan digunakan WHO, yaitu panjang/tinggi berdasarkan usia, berat badan berdasarkan usia, berat badan berdasarkan panjang/ tinggi badan, dan indeks massa tubuh (IMT) berdasarkan usia. Tiap kurva memiliki aksis X (horizontal) yang menunjukkan usia atau panjang/tinggi badan dan aksis Y (vertikal) yang menunjukkan panjang/tinggi badan, berat badan atau IMT. Hasil pengukuran akan diplot dengan mempertemukan kedua garis tersebut. Pada tiap kurva terdapat garis dengan label 0 atau median yang merupakan standar/rerata. Terdapat juga garis $Z$, yang diberikan nomor 1, 2, 3 (di atas median) dan $-1,-2,-3$ (di bawah median). ${ }^{14}$

Pola pertumbuhan normal memiliki masa percepatan (spurt) dan masa perlambatan (plateau) sehingga pergeseran pada persentil dapat terjadi. Namun, pergeseran persentil yang ekstrim perlu dimonitor, begitu juga selisih yang besar pada panjang atau tinggi badan, berat badan, dan lingkar kepala. Ketika asupan nutrisi tidak memadai, indikator yang pertama kali menurun adalah berat badan, disusul dengan tinggi badan, dan terakhir adalah lingkar kepala. ${ }^{14}$

Dengan banyaknya indikator pertumbuhan, perlu dipilih indikator yang paling sesuai karena tidak ada kesepakatan mengenai "baku emas" indikator pertumbuhan. Penilaian pertumbuhan linear paling sering menggunakan $z$-score panjang/tinggi badan terhadap usia. Untuk keperluan penelitian, terutama yang berkaitan dengan indikator pertumbuhan dan biomarker, jika dilakukan dua pengukuran tinggi badan berjarak minimal 2 bulan, dipertimbangkan untuk menilai (1) perubahan skor $\mathrm{Z}$ tinggi badan ( $\triangle \mathrm{HAZ}$ ) dalam interval minimal 2 bulan, yang disesuaikan untuk HAZ pada waktu 1 (forward analysis) atau waktu 2 (backward analysis), dan (2) kecepatan pertumbuhan kondisional. Jika dilakukan lebih dari 2 kali pengukuran tinggi badan berjarak minimal 2 bulan, dipertimbangkan untuk menilai (1) perubahan skor $\mathrm{Z}$ tinggi badan, dengan interval 3-6 bulan, yang disesuaikan untuk HAZ pada salah satu waktu, (2) kecepatan pertumbuhan kondisional, dan (3) model regresi random-effect untuk $\triangle$ HAZ.${ }^{16}$ Indikator antropometri yang biasa digunakan tertera ada Tabel 3.

Skor $\mathrm{Z}$ tinggi badan (HAZ) merupakan indikator yang sering digunakan dalam penelitian pertumbuhan. Keuntungan dari penggunaan HAZ adalah mudah untuk dihitung dan sering digunakan sehingga dapat dibandingkan dengan studi terdahulu. Kekurangan dari penggunaan HAZ tunggal adalah tidak dapat menilai pertumbuhan longitudinal. Dalam banyak penelitian, terutama untuk keperluan surveilans kesehatan masyarakat, HAZ dapat dikategorikan menjadi stunting dan dan tidak stunting. Akan tetapi, membagi populasi menjadi stunting dan tidak stunting dapat mengabaikan variasi penting pada HAZ sehingga mengurangi kekuatan studi. Besar masalah ini dapat dikurangi dengan membuat kategori multilevel, seperti normal, stunting sedang, dan stunting berat. ${ }^{13}$

Tinggi kondisional merupakan tinggi badan anak yang diasosiasikan dengan hasil pengukuran sebelumnya dengan cara meregresi HAZ saat ini dengan pengukuran sebelumnya. Dengan demikian, tinggi kondisional

Tabel 3. Indikator antropometri yang sering digunakan ${ }^{13}$

\begin{tabular}{lll}
\hline Indikator antropometri & Interpretasi & Manfaat klinis \\
\hline Berat badan terhadap usia $(\mathrm{BB} / \mathrm{U})$ & $\mathrm{BB} / \mathrm{U}<-2=$ underweight & $\begin{array}{l}\text { Berat badan berkorelasi dengan tinggi badan, asupan } \\
\text { makan, dan status kesehatan }\end{array}$ \\
$\begin{array}{l}\text { Berat badan terhadap tinggi badan } \\
(\mathrm{BB} / \mathrm{TB})\end{array}$ & $\mathrm{BB} / \mathrm{TB}<-2=$ wasted & $\begin{array}{l}\text { Tolak ukur dari malnutrisi akut, biasanya akibat } \\
\text { kurang asupan makanan atau penyakit berat }\end{array}$ \\
$\begin{array}{l}\text { Panjang badan terhadap usia }(\mathrm{PB} / \mathrm{U}) \\
\text { Tolak ukur pertumbuhan linear pada anak usia 0-1,99 } \\
\text { tinggi badan terhadap usia }(\mathrm{TB} / \mathrm{U})\end{array}$ & $\mathrm{PB} / \mathrm{U}<-2=$ stunted & $\begin{array}{l}\text { Tolak ukur pertumbuhan linear pada anak usia } \geq 2 \\
\text { tahun }\end{array}$ \\
$\begin{array}{l}\text { Indeks massa tubuh (IMT) } \\
\text { Lingkar lengan atas (LLA) }\end{array}$ & Z-score IMT & $\begin{array}{l}\text { Tolak ukur anak kurus/gemuk } \\
\text { Tolak ukur malnutrisi akut, terutama pada malnutrisi } \\
\text { akut berat }\end{array}$ \\
Lingkar kepala (LK) & Tolak ukur pertumbuhan otak \\
\hline
\end{tabular}

Diadaptasi dari : Wit JM dkk ${ }^{13}$ 
Aman B. Pulungan: Auxology, kurva pertumbuhan, antropometri, dan pemantauan pertumbuhan

Tabel 3. Pola pertumbuhan yang membutuhkan evaluasi lanjutan ${ }^{14}$

\begin{tabular}{lll}
\hline Pola & Kemungkinan diagnosis & Evaluasi lanjutan \\
\hline Berat badan, panjang badan, dan & Perawakan pendek familial & Tinggi midparental \\
lingkar kepala $<$ persentil 5 & Perawakan pendek konstitusional & Perkembangan pubertas \\
& $\begin{array}{l}\text { Pertumbuhan janin lambat } \\
\text { Abnormalitas genetik }\end{array}$ & Riwayat prenatal \\
Ketidaksesuaian persentil & $\begin{array}{l}\text { Analisis kromosom } \\
\text { konstitusional) }\end{array}$ & Tinggi midparental \\
& Kelainan endokrin & Hormon tiroid \\
& Nutrisi tidak adekuat & Hormon pertumbuhsn \\
& Catch-down growth & Perkembangan pubertas \\
Penurunan persentil & Kelainan endokrin & Riwayat penyakit dan pemeriksaan fisik \\
& Nutrisi tidak adekuat & Riwayat asupan nutrisi dan social \\
\end{tabular}

Diadaptasi dari: Levine DA dkk ${ }^{14}$

merepresentasikan deviasi seorang anak terhadap tinggi yang diekspektasi berdasarkan tinggi badan sebelumnya atau pola pertumbuhan populasi berdasarkan kurva referensi atau standar internasional. Pendekatan dengan tinggi kondisional bermanfaat karena mengoreksi regression to the mean. ${ }^{13}$

Melakukan evaluasi pertumbuhan secara berkala, pemeriksaan fisik, dan riwayat penyakit yang cermat membantu menentukan normal atau tidaknya pertumbuhan seorang anak. Kelainan pada pengukuran paling sering diakibatkan oleh kesalahan teknis. Oleh karena itu, pengukuran ulang secara teliti merupakan langkah pertama sebelum melakukan evaluasi lanjutan. Gangguan pertumbuhan tertentu berdampak pada perubahan karakteristik proporsi ukuran badan, ekstremitas, dan kepala. Perubahan karakteristik yang membutuhkan evaluasi lanjutan tertera pada Tabel $3 .{ }^{13}$

\section{Jenis-jenis kurva pertumbuhan}

Kurva pertumbuhan dapat diklasifikasikan menjadi kurva standar dan kurva referensi. Kurva referensi menggambarkan pertumbuhan sekelompok individu, umumnya dipresentasikan dalam distribusi frekuensi pada usia yang berbeda. Pada prinsipnya, kurva standar serupa dengan kurva referensi, tetapi dipilih subyek yang sehat dengan kontrol pada lingkungan subyek, seperti mendapat ASI eksklusif dan ibu tidak merokok. Oleh karena itu, kurva standar dianggap mendeskripsikan pertumbuhan anak "sehat" ${ }^{16}$ Contoh dari kurva standar adalah kurva standar WHO usia 0-2 tahun, sementara kurva referensi biasanya berbasis populasi, seperti kurva Jepang, Belanda, dan sebagainya.

Studi WHO Multicentre Growth Reference Study (MGRS) dilaksanakan pada tahun 1997-2003 dan mengambil sampel dari enam negara, yaitu Brazil (Amerika Selatan), Ghana (Afrika), India (Asia), Norwegia (Eropa), Oman (Timur Tengah), dan Amerika Serikat (Amerika Utara). Terdapat dua komponen dari studi ini, yaitu (1) penelitian longitudinal, di mana anak diikutsertakan dari lahir sampai usia 24 bulan, dan (2) penelitian potong lintang, yang melibatkan anak usia 18 sampai 71 bulan. ${ }^{17-19}$ Populasi studi dipilih berdasarkan kondisi sosio-ekonomi yang mendukung tumbuh kembang optimal, dengan morbiditas rendah dan $\geq 20 \%$ ibu memberi ASI eksklusif. Ibu dan anak yang termasuk dalam kriteria studi adalah tidak adanya hambatan pertumbuhan dalam bidang kesehatan, lingkungan, atau ekonomi; ibu bersedia mengikuti rekomendasi pemberian makan; kelahiran cukup bulan ( $\geq 37-<42$ minggu) dan tunggal; tidak ada morbiditas signifikan; serta ibu tidak merokok sebelum dan sesudah melahirkan. ${ }^{17-19}$

Besar sampel total untuk studi longitudinal dan potong lintang adalah 8440 anak, dan 1737 anak termasuk dalam sampel longitudinal. Ketika dibandingkan dengan kurva CDC 2000, terdapat perbedaan bermakna berat badan terhadap usia terutama pada masa bayi, yang diduga dipengaruhi oleh desain studi dan asupan nutrisi. Selain itu, didapatkan bahwa anak di Amerika Serikat lebih berat dibandingkan 
Aman B. Pulungan: Auxology, kurva pertumbuhan, antropometri, dan pemantauan pertumbuhan

Tabel 1. Interpretasi kurva pertumbuhan WHO

\begin{tabular}{|c|c|c|c|c|}
\hline \multirow[t]{2}{*}{ Skor z } & \multicolumn{4}{|c|}{ Indikator pertumbuhan } \\
\hline & $\mathrm{PB}$ atau $\mathrm{TB} / \mathrm{U}$ & $\mathrm{BB} / \mathrm{U}$ & $\mathrm{BB} / \mathrm{TB}$ & IMT/U \\
\hline$>3$ & (poin 1) & (Poin 2) & Obesitas & Obesitas \\
\hline$>2$ & & & Overweight & Overweight \\
\hline$>1$ & & & Possible risk of overweight (poin 3) & Risiko overweight (poin 3) \\
\hline \multicolumn{5}{|c|}{0 (median) } \\
\hline \multicolumn{5}{|l|}{$<-1$} \\
\hline$<-2$ & Stunted (poin 4) & Underweight & Wasted & Wasted \\
\hline$<-3$ & Severely stunted (poin 4) & Severely underweight & Severely wasted & Severely wasted \\
\hline
\end{tabular}

standar WHO dan terdapat perbedaan yang signifikan pada kurva IMT terhadap usia. ${ }^{18}$

De Onis $\mathrm{dkk}^{20}$ menilai penggunaan kurva standar WHO pada tahun 2011 dan mendapatkan bahwa dari 219 sampel negara, $75 \%$ menggunakan, $17 \%$ sedang mempertimbangkan, dan 7\% tidak menggunakan kurva standar WHO. Alasan utama tidak digunakannya kurva standar WHO adalah preferensi terhadap referensi lokal.

Kesesuaian kurva standar WHO untuk diterapkan di seluruh negara terus diteliti. Natale $\mathrm{dkk}^{21}$ membandingkan data WHO dari studi MGRS dengan data penelitian dari 55 negara, dan mendapatkan bahwa tinggi badan bervariasi antarnegara dan kelompok etnis. Rerata tinggi badan umumnya berada dalam 0,5 SD dari rerata MGRS. Berat badan lebih bervariasi dari tinggi badan.

\section{Kurva Referensi Lokal di Indonesia}

Walaupun kurva WHO dirancang untuk digunakan secara global, beberapa negara memilih untuk menggunakan kurva referensi lokal. Sebagai contoh, anak usia 0-5 tahun di negara Eropa Utara lebih tinggi dibandingkan kurva standar WHO. ${ }^{22,23}$ Pemilihan penggunaan kurva berpengaruh ketika menganalisis pertumbuhan longitudinal anak di berbagai negara untuk menentukan perawakan pendek, terutama pada anak dengan patologi tertentu.

Saat ini, Indonesia menggunakan kurva standar WHO 2006 untuk anak berusia di bawah lima tahun, sementara untuk anak $>5$ tahun digunakan kurva CDC 2000. Berbagai studi telah mencoba membuat kurva berdasarkan data anak Indonesia, di antaranya adalah Batubara dkk ${ }^{24}$ pada tahun 2005.

Kurva nasional Indonesia dibuat pada tahun 2018 berdasarkan data Riset Kesehatan Dasar (Riskesdas) 2013, data lebih dari 300,000 anak dan remaja di 33 provinsi. Didapatkan bahwa tinggi badan (z-score) lebih rendah dibandingkan kurva standar atau referensi WHO. Tidak didapatkan hubungan yang bermakna antara tinggi badan dengan pendapatan per kapita dengan tinggi badan dewasa, tetapi berkorelasi dengan padat penduduk. Selain berat dan tinggi badan, terdapat perbedaan antara IMT anak Indonesia dengan kurva referensi/standar WHO. Selain pada masa bayi, anak dan remaja Indonesia lebih berat, dan IMT akan menurun di bawah referensi WHO pada fase remaja akhir. Pola pertumbuhan Indonesia menyerupai populasi Jepang normal. ${ }^{25}$ Kurva nasional Indonesia tertera pada Gambar 2.

\section{Kesimpulan}

Meskipun pemantauan pertumbuhan sudah dilakukan selama lebih dari 100 tahun, tetapi dalam praktek sehari-hari, implementasinya belum optimal hingga kini. Setiap anak yang pertumbuhannya melambat, turun dari garis persentil kurvanya setelah umur 3 tahun, tinggi badan di bawah persentil 3 atau jelas di bawah potensi genetik dapat dicurigai sebagai gangguan pertumbuhan dan harus segera ditindaklanjuti.

Deteksi gangguan pertumbuhan dapat dilakukan dengan pengukuran panjang/tinggi, berat badan dan secara berkala sesuai rekomendasi. Tindakan terpenting yang harus dilakukan dokter dan orang tua adalah deteksi dini. Hal ini dilakukan dengan pemantauan pertumbuhan setiap bulan untuk balita, dan untuk tinggi badan pada anak $<1$ tahun diperiksakan saat lahir, 1, 2, 4, 6, 9, 12 bulan; usia 1-2 tahun setiap 3 bulan, dan satu tahun sekali untuk anak yang lebih besar. Keterlambatan diagnosis dan tata laksana gangguan pertumbuhan menyebabkan potensi genetik anak untuk tinggi tidak tercapai dan anak menjadi pendek. 
Kurva Referensi Pertumbuhan Nasional $\square$ UNTUK ANAK LAKIILAKI INDONESIAO'

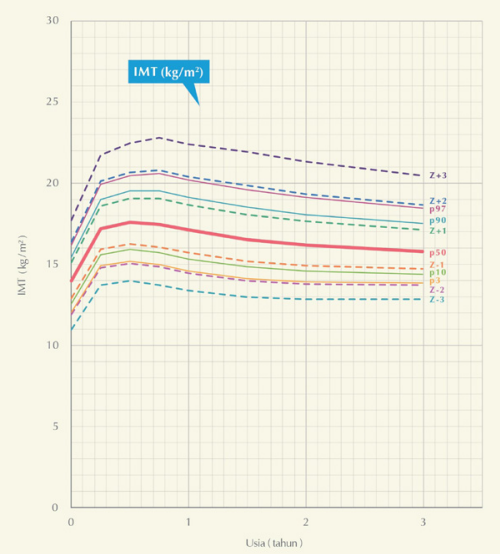

Kurva Referensi Pertumbuhan Nasional

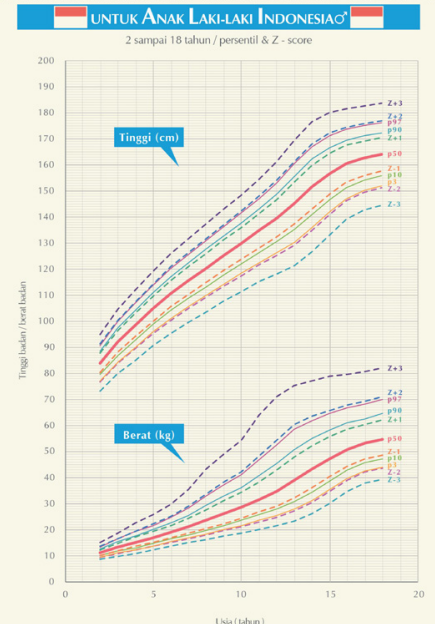

Kurva Referensi Pertumbuhan Nasional

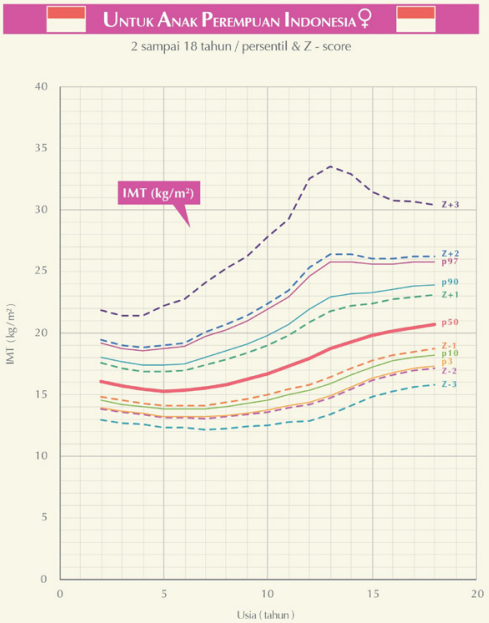

Kurva Referensi Pertumbuhan Nasional
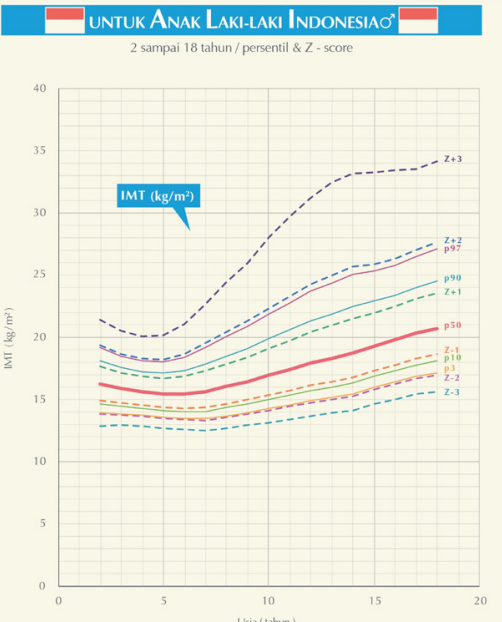

Kurva Referensi Pertumbuhan Nasional

$\square$ untuk Anak Lakl-Laki Indonesia o

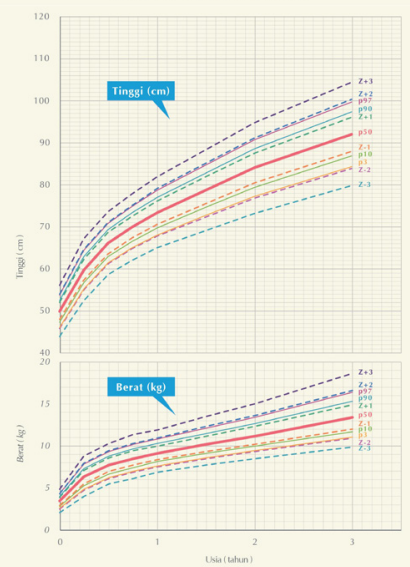

Kurva Referensi Pertumbuhan Nasional
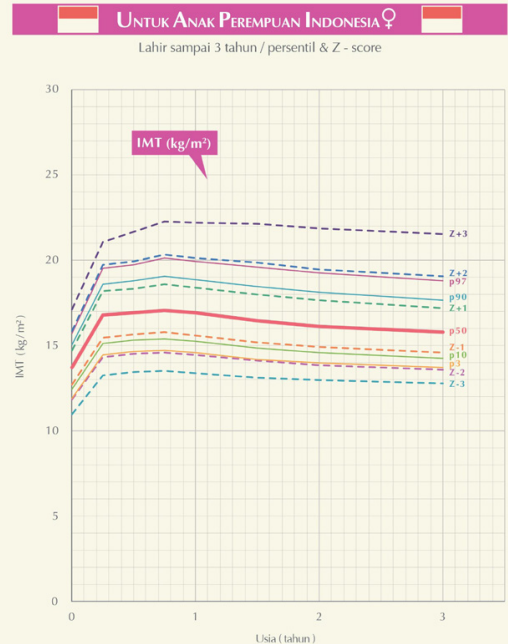

Kurva Referensi Pertumbuhan Nasional $\square$ UntuK Anak Pregnuan INDONGSA?

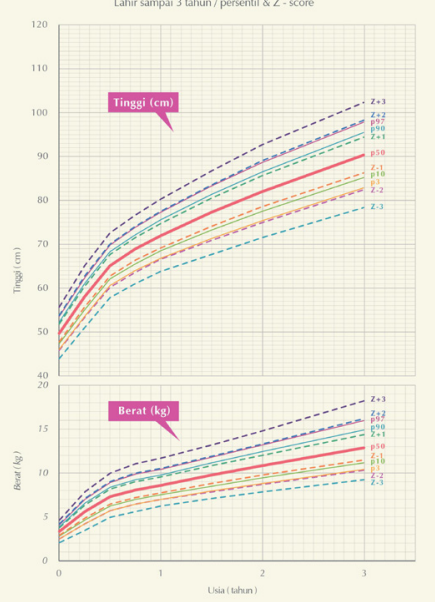

Kurva Referensi Pertumbuhan Nasional

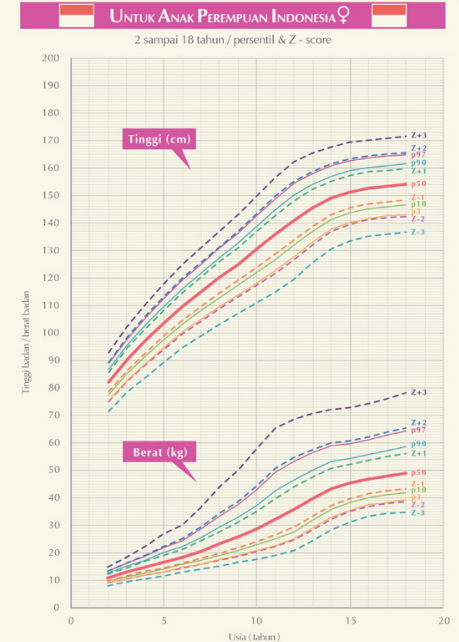

Gambar 2. Kurva referensi pertumbuhan nasional anak Indonesia ${ }^{15}$ 
Aman B. Pulungan: Auxology, kurva pertumbuhan, antropometri, dan pemantauan pertumbuhan

\section{Daftar pustaka}

1. Cole TJ. The development of growth references and growth charts. Ann Hum Biol 2012;39:382-94.

2. Kuczmarski RJ, Ogden CL, Guo SS, Grummer-Strawn LM, Flegal KM, Mei Z, dkk. 2000 CDC growth charts for The United States: methods and development. Vital Health Stat 2002;11:1-190.

3. De Onis M, Garza C, Onyango AW, Borghi E. Comparison of the WHO child growth standards and the CDC 2000 Growths Charts. J Nutr 2007;137:144-8.

4. Grummer-Strawn LM, Reinold C, Krebs NF. Use of World Health Organization and CDC growth charts for children aged 0-59 months in the United States. MMWR Recomm Rep 2010;59:1-15

5. De Onis M, Yip R. The WHO growth chart: historical considerations and current scientific issues. Bibl Nutr Dieta 1996;53:74-89.

6. Kerac M, Blencowe H, Grijalva-Eternod C, McGrath M, Shoham J, Cole TJ, dkk. Prevalence of wasting among under 6-month-old infants in developing countries and implications of new case definitions using WHO growth standards: a secondary data analysis. Arch Dis Child 2011;96:1008-13.

7. Johnson W, Vazir S, Fernandez-Rao, Kankipati WR, Balakrishna N, dkk. Using the WHO 2006 child growth standard to assess the growth and nutritional status of rural south Indian infants. Ann Hum Biol 2012;39:91101.

8. Soedjatmiko. Deteksi dini gangguan tumbuh kembang balita. Sari Pediatri 2001;3:175-88.

9. Batubara J, Alisjahbana A, Gerver-Jansen A, Alisjahbana B, Sadjimin T, dkk. Growth diagrams of Indonesian children: The nationwide survet of 2005. Paediatrica Indones 2006;46:118-26.

10. Hermanussen M. Auxology: An Update. Horm Res Paediatr 2010;74:153-64.

11. Brook CGD. Growth. Dalam: A guide to the practice of paediatric endocrinology. Cambridge: Cambridge University Press; 1993.h.18-54.

12. Hermanussen M, Bogin B. Auxology - an editorial. Italian J Pediatrics 2014; 40 . doi.org/10.1186/18247288-40-8.

13. Wit JM, Himes JH, Buuren Sv, Donna M. Denno DM, Suchdev PS, dkk. Practical application of linear growth measurements in clinical research in low- and middle- income countries. Horm Res Paediatr 2017;88:79-90.

14. Levine DA. Growth and development. Dalam: Marcdante KJ, Kliegman RM, penyunting. Nelson Essentials of Pediatrics. Edisi ke-8. Philadelphia: Elsevier; 2015.h.151-5.

15. Ikatan Dokter Anak Indonesia. Pedoman pelayanan medis IDAI. Jakarta: Ikatan Dokter Anak Indonesia; 2010.

16. Cole TJ. The development of growth references and growth charts. Ann Hum Biol 2012;39:382-94.

17. WHO Multicentre Growth Reference Study Group. Assessment of differences in linear growth among populations in the WHO Multicentre Growth Reference Study. Acta Paediatr 2006;Suppl 450:56-65.

18. WHO Multicentre Growth Reference Study Group. Enrolment and baseline characteristics in the WHO Multicenthe Growth Reference Study. Acta Paediatr 2006; Suppl 450:7-15.

19. de Onis M, Garza C, Victora CG, Onyango AW, Frongillo EA, Martines J. The WHO Multicentre Growth Reference Study: planning, study design, and methodology. Food and Nutr Bull 2004;25:S15-26.

20. de Onis M, Onyango A, Borghi E, Siyam A, Blossner M, Lutter C. Worldwide implementation of the WHO Child Growth Standards. Public Health Nutr 2012;15:1603-10.

21. Natale V, Rajagopalan A. Worldwide variation in human growth and the world health organization growth standards: a systematic review. BMJ Open 2014; 4:e003735.

22. Juliusson PB, Roelants M, Hoppenbrouwers K, Hauspie R, Bjerknes R. Growth of Belgian and Norwegian children compared to the WHO growth standards: prevalence below 22 and above +2 SD and the effect of breastfeeding. Arch Dis Child 2011;96:916-21.

23. Rosario AS, Schienkiewitz A, Neuhauser H. German height references for children aged 0 to under 18 years compared to $\mathrm{WHO}$ and CDC growth charts. Ann Hum Biol 2011;38:121-30.

24. Batubara J, Alisjahbana A, Gerver-Jansen AJGM, Alisjahbana B, Sadjimin T, dkk. Growth diagrams of Indonesian children: The nationwide survey of 2005. Paediatr Indones 2006;46:5-6.

25. Pulungan $A B$, Julia M, Batubara JRL, Hermanussen M. Indonesian national synthetic growth charts. Acta Sci Paediatrics 2018;1:20-34. 